PART 3

Embeddedness 
Abdoulaye Sounaye - 9789004356368

Downloaded from Brill.com@4/26/2023 01:53:25AM via free access 


\title{
Salafi Youth on Campus in Niamey, Niger: Moral Motives, Political Ends
}

\author{
Abdoulaye Sounaye
}

In a conversation about current religious practice on the campus of Abdou Moumouni University (Université Abdou Moumouni, UAM), Niamey, Niger, ${ }^{1}$ a colleague of mine, addressing a former classmate, asked, "Do you remember when we were in high school [Lycée] in Tahoua, how many of us were practicing Muslims? Please, tell them: who was going to the mosque at that time?" As the other man hesitated, my colleague continued, "Almost nobody; we didn't even have a proper mosque, just a corner delineated by some gravel next to the dorms. And let me tell you: those who ventured to pray, we teased and made fun of them. We 'lynched' them when they came back from the mosque." ${ }^{2}$

Today, based on the number of students who flock to campus mosques during daily prayers, Islam-related posters and announcements that jam postingboards and the circulation of Islamic pamphlets among female students, those times of unreligious students are long time gone. Welcome to the religionconscious student and the Salafi activist! In fact, one may need a few days to realize the reversal in the roles my colleague evokes above, but only a few hours to grasp the significance of Islamic revival in an arena that was until recently the training ground for many Marxist-Leninists, in particular those who ran the student organization (USN, Union des Scolaires Nigériens) before they went on to lead political parties and civil society organizations. Obviously the dominant ideology on campus through the 1990s, Marxism-Leninism has been slowly outplayed by Islamic activism, following what I would call the religious turn that has transformed campus politics and the moral economy of Nigerien society as a whole.

That young people schooled in Western educational institutions were not religious was simply a cliché that ran deep in the popular imagination of Yan Boko (Western educated, in Hausa) and was widespread in this former French colony where the school system as a moral fabric, the state institutions and the political regime, are still heavily influenced by French moral and political

\footnotetext{
1 UAM from now on.

2 NB: I use nicknames to insure the privacy of my interlocutors.
} 
philosophy. The separation between state and religion, the prohibition of religious political parties and of religious education in the public school system, are some of the features of this secularism. ${ }^{3}$ Because the public school system is grounded in a French republicanism that posits a radical secularism (laïcité), for many reasons the idea of a young student engaging in religious practice was simply out of the ordinary and, in many contexts, not only unexpected but also paradoxical. Heirs and products of this political philosophy, university students were naturally viewed as the vanguards of this moral order which gave little room to religiosity and subordinated religion to the state.

This chapter examines Salafism at UAM, focusing on the Association des étudiants musulmans du Niger à l'université abdou moumouni de Niamey (AEMN/UAM) the main Islamic organization on campus. It draws on a series of conversations conducted and observations made from 2013 to 2015. Salafism is defined here as a practice that models religiosity along the lines of Muhammad and the pious ancestors (Salaf) (Thurston 2016; Lauzière 2015; Sounaye 2015; Marks 2013; Pall 2013; Østebø 2011; Meijer 2009), and emphasizes a ritual purity that rests on the imperative to ground Islamic practice in an absolute monotheism (tawhid). In its local manifestation, it rejects the mysticism and esoterism generally associated with the Sufi organizations (tariqa), but also local customs and practices ( $a l a d u$ ) including divination and the use of charms or talismans. It equates those practices with unlawful innovations (bid'a) and polytheism (shirk) of which a true Muslim society should rid itself. In the last two decades, these claims of authenticity have become appealing to many, in particular schooled youth among whom Salafi rationalism and emancipatory discourse have recruited some of its most committed supporters.

As a religious trend and a social movement, Salafism became popular in Niger only recently. Three major factors played into the development: Saudi initiatives in Islamic learning and $d a^{c} w a$ (proselytizing) especially through The World Assembly of Muslim Youth and the Muslim World League; the influence of Northern Nigeria where Salafism has become a major force; and the social roles the graduates of the University of Medina took on upon their return to Niger. The intellectual and theological genealogies of the Salafi discourse in Niger and on the UAM campus in particular, go back to the ideas and positions of scholars such as Ahmad ibn Hanbal (780-855), founder of one of the four main legal schools in Islam, Ibn Taymiyya (1263-1328) and Abd al Wahab $\left(1703^{-1792)} \cdot{ }^{4}\right.$ The last two have proved popular anti-Sufi scholars who have

3 For a discussion on Islam and laïcité in Niger, see Sounaye 2009b.

4 Recent conversations I had with some students suggest also a growing influence of Tariq Ramadan whose publications are used to promote a modernist salafism, so to speak. 
inspired Islamic reform across West Africa in part with Saudi support channelled through a local elite eager to counter Sufism and the influence of secular ideologies in particular laïcité and Marxism-Leninism. In general, Salafism has empowered young people to lay the ground for appropriations that, on the one hand, transcend generational, ethnic and class divides and, on the other, promote religious self-consciousness, ${ }^{5}$ self-making and assertive attitudes (Sounaye 2012).

How do young Salafi implement their idea of a Muslim student? What initiatives have they taken? What do these initiatives say about their aspirations to transform public religiosities? How does this activism translate beyond the campus? These are questions that anyone familiar with the UAM campus even a decade ago would certainly be asking today as she or he tries to make sense of the ways in which Salafi discourse, spaces and subjects are socially produced. The chapter also highlights the processes through which students' social engineering takes over all other ideologies - religious or not - and redefines the modes of socialization and formation of elites. To echo a point that has been regularly made, "youths are neither universally manipulated nor passive actors in a world designed by others but individuals who are trying to chart their own course" (Abbink and Kessel 2004, 9). In that sense, the students on whom I focus are not confined to waiting, but are clearly engaged in a social movement for which religiosity becomes a moral resource and a political asset.

Scholars have used many metaphors and vied, with conceptual imagination, to describe the predicaments and social becoming of youth in Africa. In fact, youth have been characterized as "makers and breakers" (Boeck and Honwana 2005), "vanguards or vandals" (Abbink and Kessel 2004), the "sacrificed generation" (Sharp 2002), caught in "waithood" (Honwana 2012; Dhillon and Yousef 2009; Singerman 2007), and subjects whose "hope is cut" (Mains 2011). While they "dream of a great future for themselves" (Falola 2004, 2), they build the bridge that connects generations, value systems and communities (Burton and Charton-Bigot 2010; Masquelier 2010). According to these characterizations, youth are not stuck with only faith and luck; they also make faith their luck, while they try to come to terms with the realities of their social, political and moral environments. The so-called Arab Spring in the Middle East and North Africa, the Y'en a marre movement in Senegal, and the Balai Citoyen in Burkina Faso, are all instances of youth agency and transformative social action that target social and moral orders. Part of the argument here is to say that there is

5 I want to stress here that the Salafi attitude is not just about awareness, but more than that; it cultivates a consciousness that is supposed to shape all views, attitudes and actions in whatever context the Salafi might find him or herself. 
more than waiting, exclusion and resignation precisely because in navigating (see Christiansen et al. 2006) the social world, students deploy imagination and exert particular forms of agency aimed at reconstructing their social, political and moral conditions. As I shall show, AEMN/UAM students articulate both moral norms and political concepts in which they ground their roles, lives, status and visions of the future (Piot 2010). Understanding how these social actors - and not simply as adults in the making - see themselves, operate, act and build their groups and communities is central to theorizing social becoming and political action in Niger today.

I structure the chapter in four sections. In the first, I provide some background to help understand the process I examine. Then, I introduce the AEMN/UAM and discuss how members of this organization perceive their campus as the training ground for students fully committed to advance Salafism. In many ways, following in the footsteps of the prophet Muhammad - a feature of their religiosity - is now the driving force of what I call the social curriculum of the campus. The third section discusses how some of the Salafi ideas feed that curriculum. In the last section, I show how, while focusing on the campus, the real goal of Salafi students is to get rid of secular values and re-Islamize the society. The hope is that in a trickling effect, and channelled by the agentive power of this elite in the making, Salafi ideas and values will spread into the society as a whole.

\section{The Religious Turn on Campus}

The UAM was created in 1971 in order to respond to the demand of civil servants in a country at the time still dependent on France and the neighbouring countries to administer its state system. Consequently, until the end of the 1980 , the UAM was central to the social and economic policies of Niger. As one graduate put it: "Graduating from UAM carried prestige and ensured you a good job." With around twenty thousand students today, the UAM is still the main higher education institution in the country and, as one could also imagine, an arena of contestation of state policies. In that regard, its students have played a historic role, especially in the 1990s as the country was transitioning to constitutional rule. Their strikes and demonstrations calling for better study and living conditions have regularly added to tense political situations, which, in some cases, ended up in military interventions and take-overs (1996, 1999 and 2010).

6 Issa, graduated in 1986. 
Since the 1990s, and following a global trend, Islam has acquired an unprecedented popularity in Niger, becoming an even more important factor in the religious field and one of the most audible public discourses. Salafism has been key to this development as it spread across urban areas, in particular among Western-educated constituencies, redefining interactions and governability. ${ }^{7}$ This is illustrated by the way Salafi youth organizations have set up the infrastructural basis for their interactions between the religious and the political arenas, while they are gradually transforming the conditions of civic engagement, moral activism, social agency and therefore governance in general. Indocile, they have cultivated and popularized anti-Sufism, the main trait of their engagement with the religious sphere, created social spaces and promoted initiatives that are all aimed at transforming moral and political orders in the country.

It is worth noting that in their pursuit of higher education, most UAM students had to leave the relative security of their hometowns to settle in Niamey and therefore face the challenges of living in the city. At this critical juncture in their lives, large numbers come from hundreds of kilometres away, to experience living with peers in an unfamiliar setting. While many seek an aunt, uncle or simply an acquaintance with whom to stay, others have no alternative but to pile into the university dorms. A two-student room usually welcomes three or even four more, as students have to stretch the room and draw on all forms of solidarity and affinities (former schoolmates, same town or region, same discipline, same Islamic organization, etc.).

They are then compelled to create their own social networks, a process now eased by religious organizations. "Niamey estméchante et sanspitié," (lit. Niamey is harsh and ruthless) is a view that many express as they become acquainted with the moral predicaments of daily life in Niamey, adjust to new social codes and face new challenges and apprehensions. Pointing to urban anxieties and fears of immorality, student activists emphasize the need to "morally protect students who may easily get caught" and be lost to various temptations of the city (idleness, alcohol drinking, sexual promiscuity, libertinism or even smoking). It is within this context that Salafism emerges as a major discourse which seeks to provide a moral discipline, and therefore social security, to students who are viewed as spiritually weak and at risk.

This narrative about the power of Islam to morally armour students, "not simply against the temptations of the city, but also against its aggressions," as

7 I use this term to refer to the ways in which communities, groups and individuals interact with institutions and authorities to make possible the implementations of specific rules, orders and policies. 
a Law student put it, provides Salafi initiatives (a literacy program, preaching, lectures, etc.) with legitimacy and justification on the UAM campus. This is significant, especially when one considers that for a long time the UAM was perceived as a sanctuary for secular ideologies, for "only a few would actually pray and follow the prescriptions of Islam," ${ }^{8}$ although most of them would claim to be Muslim and offspring of Muslims. Militant in their attempts to improve their study and living conditions, UAM students have regularly taken to the streets to make their voices heard and their demands met. Similar to their counterparts on most African University campuses, their main ideological frame and phraseology were borrowed from the Marxist class struggle paradigm, as they claim to be the "sons and daughters of the countryside".

In short, as a former leader of the Union des Etudiants du Niger à l'Université de Niamey (UENUN) put it, "Before, religion didn't matter on this campus." ${ }^{9}$ Today, Salafism has invited itself into campus life, while its discourses have overshadowed the Marxist-Leninist ideology that shaped debates, societal visions, political cultures and even the ways in which students viewed their role as citizens throughout the 1990s. At the quotidian level, the phrase 'chers camarades' (dear comrades), the popular and emblematic words of address in campus speech has now been overtaken and replaced by "chers frères et soeurs" (dear brothers and sisters), the typical formula among Muslim activists. I have heard students referring ironically to Salafi activists saying, "They are chers-frères," illustrating some of the ways in which words of address have become important in this social context. ${ }^{10}$

To understand the influential role religiosity might have - and is already having - in Niger's politics and elite interactions, one need only look at UAM campus. In recent years, mosques and Islamic learning circles have emerged in a number of different faculties, with some having more than one. The Africa Muslims Agency (AMA), an organization mainly funded by Kuwait and Saudi Arabia, has been a key sponsor of these developments in Niger and across Africa (Sounaye 2011.) On the UAM campus in particular, and due to a renewed interest in Islam among both students and faculty members, AMA has built mosques and provided reading materials, a strategy that focuses on space-making and the formation of an elite. Understood in context, this move envisions the promotion of Islamic values and norms through the gradual Islamization

8 Gandou, MA English, graduated in 2011.

9 Ismael, MA Psychology, graduated in 1998.

10 There is certainly a whole research project one could develop on the language of Salafism and the ways in which it construes the world and becomes the repository of a worldview. 
of the social fabric of an elite that has been crucial in governing the society and producing its norms.

There is, however, more than policy and development interventions to account for the rise of Salafism on campus. One must also consider the ways in which Islamic revival as a whole has become so prevalent in the broader social context (Sounaye 2009b). Generally speaking, it is fair to say that 199os' political liberalization and constitutional governance became the catalyst of a re-Islamization process that has now reshaped the public sphere. In Egypt and Indonesia, for example, similar trends have been observed as marginalized or hitherto invisible social actors emerge to redefine the cultural, political and even the economic role of Islamic revival (Hirschkind 2013; Mahmood 2011; Rudnyckyj 2010). In the present context, it is worth noting that as Islam gains publicity, embracing Salafism is equated with being modern and breaking from traditional power structures and modes of social control that are deemed alienating. It is then not surprising that among university students, usually viewed as the products and custodians of political and cultural modernity, Salafism is gaining popularity and becoming a sign of distinction, which bestows additional social capital.

\section{The Association des Etudiants Musulmans du Niger (AEMN) and the Demand for Islam}

There are many religious organizations and groups on the UAM campus including Muslim, Christian (Groupe Biblique, Campus pour Christ, etc.) and Baha'i. ${ }^{11}$ But, the most active is the AEMN/UAM. Over the years, this organization has developed into the main agent of re-Islamization of the campus through the promotion of Salafism and a systematic rejection of laicité. The AEMN/UAM was preceded by the AEMUN (Association des Etudiants Musulmans à l'Université de Niamey), legally authorized in 1991 but banned in 2000 following their alleged involvement in violent demonstrations against the Festival International de la Mode Africaine. It was legalized again a few years later, but had to restructure and change its denomination. It then took the name AEMN/UAM in 2010, becoming only a part of the national umbrella organization of the AEMN that now has branches in every public university in the country.

11 A monotheistic religion, which originated in Persia and spread to Niger in the middle of the 2oth century. It has struggled to make much inroad, counting at best only a few hundred followers. 
A steering committee and several ad hoc committees help develop and manage the organization. For example, each faculty (Agronomy, Humanities and Social Sciences, Sciences, Law and Economics, and Health Sciences) has its own da'wa (call to Islam, proselytizing) committee. Similarly, each mosque has its committee (Comité de Gestion des Mosquées) in charge of cleaning, gathering mats for prayers and various other activities including movie viewing. Arabic literacy, Qur'anic lessons, cleaning public spaces and a set of activities they list under the category of $d a^{c} w a$ (lectures, conferences, sermons) make up the activity program. Members' voluntary contributions, in particular when they are paid their stipend, are the major source of funding for the organization. However, on the side, the AEMN/UAM also runs a bookshop, a printing service which helps duplicate and distribute reading materials, ${ }^{12}$ produces Le Messager, its monthly newsletter, and subsequently funds activities whenever external funding is not available.

According to its constitution, the main objectives of the AEMN/UAM are "to train its members to know and better understand Islam" (oeuver à la formation de ses membres pour une connaissance et une bonne comprehension de l'islam) and contribute to the social and economic development of Niger. Thus, activities are organized throughout the year to fulfil this mission. As an illustration, the mosque of the Faculty of Agronomy hosted a lecture on November 2oth 2014 to welcome newly registered students who "needed to be taught the cultural stakes (enjeux) of being a student in Niamey". According to Bashir, the guest-lecturer, the AEMN/UAM has the responsibility "to change the image of the UAM student who used to be Marxist and prone to unreligious behaviour because of laïcité." He later added:

I graduated from this institution. When I landed here, I knew almost nothing about Islam, but by the end of my studies, I learned enough to give back to my fellow youngsters ... I am here to give back; someone has to carry on the work [la relève doit être assurée], because I know that youth are the hope of tomorrow. If they learn Islam today, it will be for the benefit of the whole society.

At the UAM and across many other urban milieus of Niamey, this perspective explains the demand for Islam and the idea that students need the AEMN's assistance to keep themselves from being derailed and becoming prey to the moral black hole of the campus and any other non-Muslim institution. Religion

12 Its monthly newsletter, Le Messager (The Messenger), is among the most circulated of the press produced on campus. 
in this instance provides a structure, an idea reiterated in the AEMN's guide for new students, whereby to be student at the UAM is "to cultivate academic excellence and to develop and live faith in accordance with Islam".

Conversations among the Western-educated who have now embraced Salafism, regularly refer to Cheick Daouda Boureima, a graduate of the UAM, and the Imam who has been leading the Friday congregational prayer on campus for more than fifteen years. A prominent figure of Salafism in Niger and across the Sahel region, ${ }^{13}$ he targets the Western-educated elite and, since 2011, serves as the Prime Minister's advisor in religious and humanitarian affairs. His affinity with the political elite has opened many avenues for him, not only in the government and on campus, but also in diplomatic circles ${ }^{14}$ and the statecontrolled media. Most young activists view him as an inspiring role model, as a religious entrepreneur with a compelling life trajectory. In fact, after graduating from the UAM, he went on to study at the University of Medina, Saudi Arabia. Once he returned, he launched numerous initiatives including seminars, conferences and preaching, and developed a sustained media presence (radio, TV, internet, Facebook, etc.) which has made him an icon of Salafism and the prime example of the student who can successfully combine academic and religious training. This inclusive and integrated view of the two traditions has regularly led Boureima to highlight their complementarity and the need for Niger to promote social and intellectual role models such as he represents. Islamic and Western forms of education, he has argued, are not mutually exclusive and should not be understood in that way if the true Islam-based moral order needed in Niger is to be achieved.

In light of Boureima's example, a man who has also claimed to give back, UAM students frame their activities in terms of generosity and solidarity. While they stress views such as: "We have the moral obligation to share with other fellows the knowledge [of Islam] we have acquired," (Bashir); and "We are obliged to share whatever good we have," (Idriss); most Salafi students claim that "Your religiosity is your own responsibility," (Albora). Ultimately this situates rebirth, self-writing (Diagne 2008) and privatization processes at the centre of Salafi discourses and practices. In other words, in this setting, where promoting Islam was perceived as foreign until recently, dramatic conversions have become common and exemplary. If they are not already part of the process, many faculty members have witnessed their students taking the religious turn,

\footnotetext{
13 He is also the chair of La Ligue des Oulémas, Prêcheurs et Imams des Pays du Sahel, a regional organization.

14 He is arguably the Muslim scholar who has been the most involved in us Embassy initiatives, in part because of his non-violent stand.
} 
often in the face of secular ideologies, including Marxism, which they see as unfit to be on campus or in their Muslim society.

\section{Being Salafi on Campus}

Is the growing interest in Salafism on campus a reaction to an institutional make-up that wants to keep religion out of the public education sphere? The response to this question is clearly positive if we consider the content of the regularly held AEMN/UAM sermons and lectures. The issue of promoting religion in school settings, formally or informally, as part of the curriculum or extra-curricular activities, has become critical to promoters of Salafism on campus who seek to move away from the model of the unreligious and secular student. For many students, attending university is the beginning of a life transition away from parental control in which they are supposedly fully responsible for the choices they make. Nonetheless, and although decisive and transformative, the experience can be challenging and dramatic, especially for female students who are leaving home for the first time and must now rely on themselves and peers. But the experience has also translated into an opportunity to engage in religious activism and be reborn to Salafism, a discourse that has set up what I call the social curriculum. ${ }^{15}$

At the Faculty of Humanities, female students have now their own mosque where they hold some of their preaching and learning activities. As Sara, a member of the mosque committee states, "Sometimes, only women can help women; only women can help women understand what Islam is about," before adding, "we are all young here and Islam needs our support." If this last formula has become popular among students, it is certainly because it objectifies Islam and blurs lines of demarcation between social statuses or even generations, a point Albora, a third-year student in linguistics makes:

[O]nly ulama ${ }^{16}$ used to speak for Islam and tell people what the religion is about. Youngsters were supposed to just follow; women had almost no

\footnotetext{
15 I define social curriculum here as the set of activities, training programs, lectures, seminars, sermons etc. that are intended to socialize students, making them more religionconscious, while these initiatives position Salafism at the core of campus social life. Along with the academic element, I would argue that the social curriculum is a major component of the student's campus experience today. Religious scholars.
} 
place. In the western part of Niger, people even believed that until you were 40, you couldn't be a scholar; you were just expected to read the Qur'an and follow suit. Now, we know those beliefs are groundless and understanding Islam should not be about age nor gender.

One of the reasons for this vibrant development is that the AEMN has empowered students to put religiosity first and help their peers to do so, on campus and beyond, with other schooled youth. Filana, a female student in linguistics also notes:

As a Muslim, I participate in the activities of the Makaranta [Islamic learning group] in our Faculty. I am also part of the Da'wa Committee. We call our fellow students to Islam. You know, most students have to leave home after they complete high school. They move away from their parents and family members. And they are left alone to organize their lives on campus. Many are lost when they get here because they have no one to give them the orientation they need in their new life [rayuwa], and that could be a risky moment. There is no mom, and no dad; nobody around to advise or admonish you. You decide to lead the life you want. So, that's why we try to protect students from going astray. The sermons we organize help them to adjust and be aware of those risks. We draw their attention to them and provide them with the moral support and the advice they need to cope with life on campus.

As a preventive, this activism is more crucial for the young woman who faces even greater challenges and demands than young men, in particular regarding her body, as Filana adds:

When a female student attends the $d a^{\mathrm{c}} w a$ activities, she learns to behave, and understand, for example, the importance of covering her body. I don't believe it is a good thing for a woman to exhibit her body. She will understand that in order to preserve her dignity, she needs to cover up. She may not wear a Niqab [full veil], but she should cover up all her body except her hands and eyes. The Prophet's wives and the wives of his successors all behaved that way. So, when she joins the Da'wa Committee, she is not scorned if she doesn't wear the hijab. No. We approach her and calmly tell her why the hijab is important for a woman. And then, usually, she realizes that it's not because they are uncivilized that people wear the hijab. 
Another translation of this discourse on gender and self can be seen in other Salafi practices that lead to gendering space, not only in campus mosques, but also in classrooms and lecture halls. Asindama, a male student in philosophy, makes a direct connection between the call to Salafism and a developing trend: "In one of our lecture halls, it is now rare to see female and male students mingle. Usually, females are on one side and males on the other. I even noticed some clans forming among females. Those who wear the hijab, and those who do not." Another male student points to similar changes: "In the hall assigned to law students, there are areas male students are not supposed to be. We used to stay there and chitchat, but it is now 'female space'; nobody forbids us from going there, but we just don't go." Concerned, some students, like Fati, a member of the Da'wa Committee, have even suggested action to enforce a strict gender rule: "I don't like the way we sit indiscriminately; sometimes, you find a girl sitting between two male students; that's not normal and we should end that. The Sunna proscribes the mingling of sexes."

While no gender rule has been officially instituted to seat students during lectures in order to enact religious prescriptions for personal and gender space, many aggregate along gender lines and sometimes even sartorial practices, as Asindama noted above. It is not that gender has never been a matter of consideration in campus life; campus housing, for example, has always been gender specific. However, in addition to student dorms, the campus dining queues are now also subject to gender discrimination "after a request from the AEMN/UAM, in order to avoid mingling and to facilitate service". The same trend affects transportation as "We even have a student commissioned by our organization [AEMN/UAM] who makes sure that people queue according to their sex and that female students get in first." (Hanna, third-year student in psychology)

The UAM campus is replete with stories and anecdotes pointing to the significance of being, or at least appearing, a good Muslim. Yaro, a graduate of the sociology department, recalls: "A few years ago, a student running for a position in the steering committee of our organization [UENUN], added 'Leo' to his name. His opponents seized the opportunity to portray him as a Christian. He lost the election." Now, as a consequence, many candidates lobby for the support of the Muslim students' organization as they realize its influence on almost anything that relates to life on campus. One could easily imagine this turn in campus politics being carried on beyond the campus, for political antagonism or simply out of conviction. In a way, this is already happening, as many graduates of UAM have become leading voices in the dissemination of Salafi ethics and political views more broadly. 


\section{Beyond the Campus}

In the logic of the AEMN/UAM, the re-Islamization of the campus is only an intermediary goal. The ultimate achievement is to transform society and Muslim practices so that "we all follow in the path of Prophet Muhammad and his pious followers". ${ }^{17}$ Because of its cultural and political influence, it is understandable that the UAM, as a major intellectual and social institution, has become the target and the breeding ground for such a project. The moral and religious identity of the elite carries considerable weight, particularly because of the cultural agency and trend-setting power of this social category.18 That is why, as Bashir argued during his public lecture in November, 2014, "The UAM campus is the perfect place to start changing people's mindsets [changer les mentalités]."19 For, unlike the other towns from which most UAM students originate, and despite all the risks of the city, Niamey still facilitates access to Islamic learning and to the resources needed for such endeavour. To persuade his audience, he resorts to his own trajectory: "I come from more than $700 \mathrm{~km}$ away. When I got here to the UAM, I figured out I had a great opportunity to become learned in Islam. So, I got trained here while I was pursuing my degree in medicine."

This narrative of rebirth is not exceptional. On the contrary, it has become common for many UAM graduates who have taken positions across Niger in state administration, NGOs, the private sector or the numerous Islamic organizations. Like Bashir or Cheick Daouda, they usually frame their initiatives in terms of assistance, religious training (formation religieuse) and giving back to the community. With such views and social philosophies, their impact on the religious field has proved significant, as they have contributed to ushering in a new breed of leaders trained in both religious and secular systems. The least one could say today is that this process has transformed the sociological configurations of both the religious sphere and the social category produced by the Western education institutions (Yan Boko).

Thus, "We are fighting for Islam," - a slogan I have heard repeatedly in my conversations with UAM students - is not simply a rhetorical device to be added to the war of words that Muslim activists wage against remnants of what they see as colonial governance and inappropriate moral principles drawn

17 Mallam, member of the steering committee of AEMN/UAM.

18 It is common for local conversations on the street to blame the intellectual and political elite for the moral ills of society, from corruption in the state administration and the lack of employment opportunities to the several coups d'etat the country has experienced. 
from French political philosophy. ${ }^{20}$ Rather, it is the articulation of a political project designed to decolonize and morally reorder society by rejecting both secular norms and Islamic practices deemed inauthentic. What happens on the UAM campus may therefore be read as an ideological development that not only constitutes Salafism as the major source of values and norms, but also silences the Marxist-Leninist tradition which has until recently shaped students' politics, moral economy and interactions with the rest of society. ${ }^{21} \mathrm{~A}$ parallel can be drawn here with similar cases in Tunisia (Marks 2013), Gambia (Janson 2013) and Senegal (Gomez-Perez 2008) where youth rely heavily on religiosity to shape those interactions.

Overall, the rise of Salafism at the UAM echoes a gradual transformation of living conditions among Nigerien youth in general, but also a gradual transformation of moral references and paradigms in the wider Nigerien society. Breaking away from secular postcolonial nationalism, unlike their elders two decades ago, many of these students resort to a populism that builds on the appeal to adhere to the Sunna, the Qur'an and the Pious Ancestors. As ideological resources, one of the functions of these references is to provide both moral contours and substance, and the imagery through which students understand their life on campus, engage with the political order and articulate their dreams and visions.

The fact that their campus experience is transitional, both in time and space, does not make it less valuable. Quite the contrary, it is precisely this experience that "prepares them to become good Muslims" (Sara); "responsible social actors" (Albora); and "political leaders" (Filana). In this process, the AEMN provides the social curriculum, that is, the set of activities and training and socializing practices that, next to the academic curriculum, is intended to equip students with the skills and norms that would make them culturally, politically and socially relevant. Under such circumstances, in the same way the campus trained an elite that built on Marxism-Leninism and acquired relevance and influence through the 1990s, it is now providing similar conditions for students - future leaders - to build on religious activism and claims to have both the moral obligation and the social pressure to be better Muslims.

Indeed, this perspective has mobilized youth to be part of a campus activism through which they are expressing self-worth and social agency, and also formulating new political concepts which are clearly opposed to secular

\footnotetext{
20 A political philosophy usually described as anti-Islamic.

21 In that sense, there is also a socio-historical continuity between the current generation and the previous one: the campus remains a breeding ground of activism whether secular or religious.
} 
ideologies. While Salafi youth justify this activism and link it to processes in broader society, they are also opening a window onto their aspirations, providing an idea of the community they envision and the moral and ideological features of this entity. That these students insist on religious training (formation) is evidence of the rising awareness among young people of their historical role in affecting the moral economy of the society: a role they are preparing for, beginning in the premises of their academic institution. Here, unlike in many social arenas and spaces where they are said to be powerless, marginalized, disenfranchised or even subordinate, youth may initiate and mobilize, taking roles similar to those they played in the transition to multiparty politics in the 1990s or in the Tuareg rebellions of the 1990s and 2000s, two references that have marked Niger's recent history.

Abbink (2005) and McIntyre (2007) argue that when young people lack social incentives for growth and development, they look somewhere else for opportunities. The AEMN/UAM and religious activism in general could be that somewhere. For many UAM students, the struggle is about preparing themselves to face the challenges of the campus, an environment usually portrayed as morally dangerous. With no family around and at a critical juncture of their lives, young people going to the UAM are said to be at risk, exposed to both the moral potholes and black holes of the city. ${ }^{22}$ Those vices and the ills of the city justify the AEMN's initiatives. Matassa (those who are becoming) and agents of the future, as they are portrayed, Salafi students feel compelled to build an image and invest in 'advancing Islam' in an ideological context they usually frame in terms of a conflict of civilizations. In fact, they have frequently borrowed this narrative, emphasizing the need not only of ending the hegemony of laïcité - which, among other things, has favoured Marxism-Leninism - but of erasing its influence all together. In many ways, they have been successful in mobilizing support and changing the norms of campus life (hours of prayers, dress code, gendering space etc.), but also in training an elite that is carrying on the mission of re-Islamizing society at large.

If the project of secular modernity is to change society through enlightenment and reliance on a rationality that emancipates itself from religion, the Salafi project rather proposes to channel religiosity into an individual and collective rebirth in order to achieve transformation. In this undertaking, the rebirth could be borrowing from, challenging and even conflicting with the project of rational modernity. Often, as the positions I have highlighted

22 According to Kader, a student in Physics and member of AEMN/UAM, life on campus could be a pothole on the street, which could result in a flat tire, or a black hole that engulfs everything. 
suggest, Salafism is competing against the secular; and the competition has sometimes become an open conflict. That is why it seems to me that as the situation develops, UAM authorities will find themselves compelled to regulate religious activism and even social interactions on campus. The expanding influence of Salafism as it shapes the social curriculum of many students is more than an epiphenomenon; indeed, it is something of an ideological revolution that is targeting the social fabric of the elite and its moral references. However, the socio-political itineraries and moral trajectories this trend will take remain to be seen.

\section{Closing Comments}

Once the training ground for a generation that was expected to lead the country, renew state administration and take key social roles, UAM's campus now provides a new breed of leaders who combine secular education and religious training and hope to create the necessary conditions for civic life. What 'civic' would mean in this context is something that needs to be clarified. Still, from the perspective of the AEMN/UAM, since the population in Niger is vastly Muslim, anything they could undertake in the name of Islam qualifies as furthering the common good. That explains why Salafi students target the campus not only as an academic training ground, but also as a socialization space which is now playing a primary role in the agenda to transform society and implement the political and ideological alternatives they promote.

To grasp the significance of this process, one must also recognize the continuities of such developments within schooling environments. For example, many of the Salafi activists at the UAM embraced religious activism in high school (Lycée) as members of their school's Islamic Club (Club des Jeunes Musulmans, CJM), which provided them with the social, religious and cultural premises they intend to perfect once on campus. This trend has made the school space a privileged site for the popularization of the revivalist ethic of responsibility and privatization dear to Salafi discourse. As we can see from this case, while undoing specific power and ideological structures, the same discourse has also established replacements which stress not only being good Muslim, but also fitting into society.

In that sense, the UAM campus is a micro-representation of broader Niger society. Before the 199os, for example, a student who displayed commitment to religious practice would be stereotyped as "réactionnaire", a derogatory label used for students unsupportive or actively opposed to the UENUN's dominance in campus life. Shaped by a fight culture, the campus was usually viewed 
as a domain of contestation against both the moral and the political orders in place. For this reason, its discourse was clothed in Marxist-Leninist phraseology, eager to bring about the social and political changes that would insure students a bright future and the well-being of the society. Vanguards they were; vanguards they remain in many regards.

Today, in their search for a moral compass, many young Nigeriens have found in Salafism a resource to tap into, both collectively and individually, in order to fulfil their social responsibilities. This is only part of the efforts to reconstruct social norms and reassert the preeminence of an Islamic identity which, as many have complained, has been marginalized or even rejected in the moral and political philosophy of state institutions. The religious identity politics that the AEMN/UAM is promoting mainly serves the purpose of fighting this orientation.

In any case, as I have demonstrated, Salafism has introduced major transformations to campus, where the demand for Islam has given rise to thriving social engineering initiatives, in return reinforcing the role of Islam as a major source of norms. By stressing the need for students to view all dimensions of their lives through the Qur'an and the Sunna of Muhammad, the AEmn/UAm has paved the way to a religious activism that many students expect to carry beyond the campus and after graduation into their professional lives. What actual political ends this activism will achieve beyond the campus remain open and worth watching, as these students are not only imagining their own futures, but also creating the conditions of their existence as subjects, citizens and social actors.

\section{References}

Abbink, Jon. 2005. "Being Young in Africa :The Politics of Despair and Renewal." Article in proceedings. https://openaccess.leidenuniv.nl/handle/1887/9608 (accessed 3 February 2017).

Abbink, Jon, and Ineke Van Kessel, ed. 2004. Vanguard or Vandals: Youth, Politics and Conflict in Africa. Leiden; Boston: Brill Academic Pub.

Boeck, Filip De, and Alcinda Honwana, ed. 2005. Makers and Breakers: Children and Youth in Postcolonial Africa. Trenton, N.J.: Africa World Press.

Burton, Andrew and Helene Charton-Bigot, ed. 2010. Generations Past: Youth in East African History, 1st edition. Athens: Ohio University Press.

Christiansen, Catrine, Mats Utas, and Henrik E. Vigh, eds. 2006. Navigating Youth, Generating Adulthood: Social Becoming in an African Context. Uppsala: Nordic Africa Institute. 
Dhillon, Yousef and Tarik Yousef. 2009. Generation in Waiting: The Unfulfilled Promise of Young People in the Middle East. Washington, DC: Brookings Institution Press.

Diagne, Souleymane Bachir. 2008. "Toward an Intellectual History of West Africa: The Meaning of Timbuktu." In The Meanings of Timbuktu, edited by Shamil Jeppie and Souleymane Bachir Diagne, 19-27. Human Sciences Research Council.

Falola, Toyin. Teen Life in Africa. 2004. West Port: Greenwood Press.

Gomez-Perez, Muriel. 2008. “The Association Des Étudiants Musulmans de l'Université de Dakar 1 (AEMUD) between the Local and the Global: An Analysis of Discourse." Africa Today 54 (3): 95-117.

Hirschkind, Charles. 2013. The Ethical Soundscape: Cassette Sermons and Islamic Counterpublics. Columbia University Press.

Honwana, Alcinda M. 2012. The Time of Youth: Work, Social Change, and Politics in Africa. Sterling, Va: Kumarian Press.

Janson, Marloes. 2013. Islam, Youth and Modernity in the Gambia. 1st edition. Cambridge University Press.

Lauzière, Henri. 2015. The Making of Salafism: Islamic Reform in the Twentieth Century. New York: Columbia University Press.

MacIntyre, Alasdair. 2007. After Virtue: A Study in Moral Theory, Third Edition. 3rd edition. Notre Dame, Indiana: University of Notre Dame Press.

Mahmood, Saba. 2011. Politics of Piety: The Islamic Revival and the Feminist Subject. Princeton: Princeton University Press, 2005. Revised edition.

Mains, Daniel. 2011. Hope is Cut:Youth, Unemployment, and the Future in Urban Ethiopia. Reprint edition. Temple University Press.

Marks, Monica. 2013. "Youth Politics and Tunisian Salafism: Understanding the Jihadi Current." Mediterranean Politics 18 (1): 104-111. doi:10.1080/13629395.2013.764657.

Masquelier, Adeline. 2010. "Securing Futures: Youth, Generation, and Muslim Identities in Niger." In Being Young and Muslim, edited by Linda Herrera and Asef Bayat, 225-239. Oxford: Oxford University Press.

Meijer, Roel, ed. 2009. Global Salafism: Islam's New Religious Movement. First edition. C Hurst \& Co Publishers Ltd.

Østebø, Terje. 2011. Localising Salafism. Leiden; Boston: Brill.

Pall, Zoltan. 2013. Lebanese Salafis Between the Gulf and Europe: Development, Fractionalization and Transnational Networks of Salafism in Lebanon. 1st edition. Amsterdam: Amsterdam University Press.

Piot, Charles. 2010. Nostalgia for the Future: West Africa after the Cold War. University of Chicago Press.

Rudnyckyj, Daromir. 2010. Spiritual Economies: Islam, Globalization, and the Afterlife of Development. Ithaca: Expertise: Cultures and Techno.

Sharp, Lesley A. 2002. The Sacrificed Generation: Youth, History, and the Colonized Mind in Madagascar. Berkeley: University of California Press. 
Singerman, Diane. 2007. "The economic imperatives of marriage: Emerging practices and identities among youth in the Middle East." Working Paper 6. Washington DC, and Dubai: Wolfensohn Centre for Development and Dubai School of Government.

Sounaye, Abdoulaye. 2009a. "Ambiguous Secularism: Islam, Laïcité and the State in Niger." Civilisations LVIII (2): 41-57.

Sounaye, Abdoulaye. 20ogb. "Izala Au Niger: Une Alternative de Communauté Religieuse." In Les Lieux de Sociabilité Urbaine Dans La Longue Durée En Afrique, edited by Laurent Fourchard, Odile Georg, and Muriel Gomez-Perez, 481-500. Paris: L'Harmattan.

Sounaye, Abdoulaye. 2009c. "Speaking for Islam: Ulama, Laïcité, and Democratization in Niger." American Journal of Islamic Social Sciences 23: 110-127.

Sounaye, Abdoulaye. 2011. "Doing Development the Islamic Way in Contemporary Niger." Bulletin de l'APAD, no. 33 (August). http://apad.revues.org/4084 (accessed 3 February 2017).

Sounaye, Abdoulaye. 2012. "Les Clubs Des Jeunes Musulmans Du Niger: Un Espace Intergénérationnel." In L Afrique Des Générations. Entre Tensions et Négociations, edited by Muriel Gomez-Perez and Marie Nathalie LeBlanc, 166-217. Paris: Karthala. Sounaye, Abdoulaye. 2015. "Irwo Sunnance Yan-No! 1: Youth Claiming, Contesting and Transforming Salafism." Islamic Africa 6: 82-108. doi:10.1163/21540993-00602006.

Thurston, Alexander. 2016. Salafism in Nigeria:Islam, Preaching, and Politics. Cambridge University Press. 